\title{
Critical Cosmopolitan Citizenship Education and the Ontario Curriculum
}

\author{
Taciana de Lira e Silva \\ University of Ottawa
}

Critical cosmopolitan citizenship education is a transformational approach to education that empowers students to become global citizens through active involvement in the local, national and global communities while seeking to build a better world. This study's objective was to inquire about how Ontario's official curriculum guides educators to prepare secondary students (Canadian born and those new to Canada) to become effective citizens of the $21^{\text {st }}$ century. A critical discourse analysis was conducted to investigate the Ontario Ministry of Education's (OME) approach to citizenship education within the frameworks of critical pedagogy and cosmopolitan citizenship education that encourage educators and students to respect human rights and become active citizens who strive towards peace and sustainability. The discourse analysis included two curriculum documents: (1) The Ontario curriculum grades 9 and 10: Canadian and World Studies (OME, 2018), which addresses civic education, and (2) The Ontario Curriculum Grades 9 to 12: English as a Second Language and English Literacy Development (OME, 2007), which prepares newcomers to improve their English proficiency. The findings confirm that the discourse produced by these documents aims to develop students' understanding of the global world, but does not necessarily prepare them to act for the betterment of the planet. The findings further indicate that citizenship education in the $21^{\text {st }}$ century should dissociate from a nation-centered approach and focus on preparing students for global citizenry.

Keywords: cosmopolitan citizenship education, critical pedagogy, empowerment, human rights, Ontario curriculum, ESL

L'éducation à la citoyenneté cosmopolite critique est une approche transformationnelle qui habilite les étudiants à devenir des citoyens du monde qui s'impliquent activement dans les communautés locales, nationales et mondiales tout en cherchant à bâtir un monde meilleur. L'objectif de cette étude était de déterminer les différentes avenues par lequel le programme officiel de l'Ontario guide les éducateurs dans la préparation des élèves du secondaire (nés au Canada et nouveaux au Canada) à devenir des citoyens efficaces du 21e siècle. Dans le cadre d'une pédagogie critique et d'une éducation à la citoyenneté cosmopolite qui encourage les éducateurs et les étudiants à respecter les droits de l'homme et à devenir des citoyens actifs qui aspirent à la paix et au développement durable, une analyse critique du 


\section{ACTES DU SJPD-JPDS PROCEEDINGS, 2018, VOL. 2}

discours a été réalisée pour étudier l'approche de l'éducation à la citoyenneté adoptée par le ministère de l'Éducation de l'Ontario (MÉO). L'analyse du discours comprenait deux programmes d'étude: (1) le programme ontarien des 9e et 10e années: Études canadiennes et mondiales (MÉO, 2018), qui traite de l'éducation civique, et (2) le curriculum de l'Ontario, de la 9e à la 12e année: English as a Second Language and English Literacy Development (MÉO, 2007), qui prépare les nouveaux arrivants à améliorer leurs compétences en anglais. Les résultats de notre analyse confirment que le discours produit par ces documents vise à développer chez les élèves une compréhension globale du monde, mais ne les prépare pas nécessairement à agir pour le mieux-être de la planète. Les résultats indiquent en outre que l'éducation à la citoyenneté au 21e siècle devrait être dissociée d'une approche centrée sur l'État-nation pour se concentrer sur la formation des élèves à la citoyenneté mondiale.

Mots-clés : éducation à la citoyenneté cosmopolite, pédagogie critique, empowerment, droits de la personne, programme d'études en Ontario, Anglais langue seconde

Since 2017, Canada has received "illegal" refugees, many of them children, who had fled wars and hunger in their original countries and sought refuge in the United States of America. As these people were no longer welcome in that country, they decided to seek asylum in Canada; however, Canadian citizens have not been very positive about this situation. According to a poll run by the Angus Reid Institute (August 3, 2018,), 67\% of Canadians are not satisfied with the influx of illegal immigrants in this country and consider the situation a crisis. In Ontario, Premier Doug Ford demanded compensation from the federal government to pay for the care of those who entered the country illegally (Gray \& Zilio, 2018). In the midst of such a political and economic crisis, there are human beings who need a home and children who need care and education.

Globalization in the $20^{\text {th }}$ century created issues of human displacement and new financial, cultural, racial, and social relationships in all walks of life (Beck \& Sznaider, 2006). In addition, environmental challenges that could lead to the extinction of life on Earth have appropriately become a critical societal concern (Ceballos, Ehrlich, \& Dirzo, 2017). Therefore, it is reasonable to expect that education in the $21^{\text {st }}$ century should reflect and respond to these current realities. In order to effectively address these challenges, education that intends to contribute to the betterment of the planet must offer students the tools to learn about global challenges and work towards the protection of human life and the environment. These fundamental principles are defended by Cosmopolitan Citizenship Education (CCE) and Critical Pedagogy (CP). CCE is education for peace, human rights and 


\section{ACTES DU SJPD-JPDS PROCEEDINGS, 2018, VOL. 2}

sustainability (Nussbaum, 2003). It employs the terms cosmopolitan and citizenship as it aims to help learners become citizens of the world without giving up their national or local citizenship identity (Nussbaum, 1994). However, cosmopolitan citizens cannot be passive; they need to become critical of reality and work to address injustice and inequity. For this reason, CP is CCE's invaluable partner in the classroom, as an approach to education that seeks to empower individuals to actively engage in civic life (Kincheloe, 2007).

Cosmopolitan Citizenship Education has the potential to be a holistic approach to education that encompasses not only human relationships, but also human-environment interconnections. Environmental education (EE) has the objective of developing the learner's positive attitude and voluntary participation in projects that aim to conserve the environment and natural resources (Bootrach, Thiengkamol, \& Thiengkamol, 2015). It nurtures a relationship of respect that is essential for a better quality of life in the social, ecologic and economic ambits (Leblanc, 2018), both locally and globally. Therefore, EE should be integrated into CCE and CP. The amalgamation of these three approaches will enable the learner to understand local, national and global issues and concomitantly work towards the improvement of life on the planet through conscientização [conscientization] and praxis, which empower learners and educators to identify a problem, devise possible solutions, and act to solve the issue (Freire, 1972).

Democratic education and CP are interconnected educational practices (Apple \& Beane, 1995; Freire, 1972; Giroux, 2003; McLaren, 1994) that unveil the political connection between school and society while preparing learners to defend their rights and seek positive change at the national level. I have never encountered an academic work that encompasses CP and CCE, which would prepare learners to seek justice globally. Thus, I have chosen to combine CP and CCE in order to form Critical Cosmopolitan Citizenship Education (CCCE), an approach that empowers teachers and students to work together to better understand human and environmental injustices at local, national and global levels, while trying to find ways to change the status quo. For CCCE to happen, teachers and students need to understand principles of critical pedagogy, sustainability and cosmopolitan education. This critical discourse analysis study aims to identify concepts related to CCCE in two curriculum documents that guide educators to lead Ontario's secondary students in their journey to become effective citizens in society. 


\section{ACTES DU SJPD-JPDS PROCEEDINGS, 2018, VOL. 2}

\section{Critical Pedagogy}

John Dewey is considered the father of progressive education, an approach that claims that thinking and doing should engage students, broaden their learning experience, and prepare them to become active citizens of a democratic society. Dewey $(2004 / 1916)$ argues that "schools require for their full efficiency more opportunity for conjoint activities in which those instructed take part, so that they may acquire a social sense of their own powers and of the materials and appliances used" (p. 45). In addition, Dewey believed that a democratic society "must have a type of education which gives individuals a personal interest in social relationships and control, and the habits of mind which secure social changes without introducing disorder" (p. 104). Many educational philosophers developed theories that viewed education as a ground-breaking institution for social reforms. Freire, for instance, is considered the educational philosopher who most influenced the development of CP (Darder, Baltodano, \& Torres, 2003). In his seminal work, Pedagogy of the Oppressed, Freire (1972) explains that there are two types of human beings: oppressed and oppressor; and through empowering the oppressed, social changes can happen in a positive and constructive way. Like Dewey, Freire believed in changes that flourish from peaceful movements, without the use of violence or any other kind of disorder.

In addition to social changes, power can also promote relations of equality between humans and nature to change the present dichotomous worldview that sees the environment as an object to serve humanity. Foucault and Gordon (1980) assert that power is productive in that "it produces things [...], forms of knowledge, [and] produces discourse. It needs to be thought of as a productive network which runs through the whole social body" (p. 119). Foucault did not state that power was good or bad, but that it produces changes. CP fosters a relationship of co-builders of knowledge between teacher and student, empowering the learner to think critically and to try to transform the world (Freire,1972). Freire explains that if the teacher does not give the learner the opportunity to participate in her/his own learning, knowledge will be deposited in the learner's head and will impede critical thinking and knowledge ownership, creating oppression. This is the banking model concept, which allows student action only "as far as receiving, filling, and storing the deposits" (p. 58).

\section{Cosmopolitan Citizenship Education}

Cosmopolitan citizenship education (CCE) aims to help learners become citizens of the world without giving up their local or national allegiance. In emphasizing a common humanity and human solidarity, cosmopolitanism does not seek to deny local or regional 


\section{ACTES DU SJPD-JPDS PROCEEDINGS, 2018, VOL. 2}

identifications (Osler, 2011), but to emphasize them. As Nussbaum (1996) and Appiah (2006) note, local identities remain important for cosmopolitans because they can be a source of great richness.

Nussbaum (1994) explains that cosmopolitan citizenship is an approach that was first defended by Diogenes (the cynic) and the Roman stoics. Kant (1903) defended the right of universal hospitality, "the claim of a stranger entering foreign territory to be treated by its owner without hostility" (p. 137) and clarified that humans are first and foremost citizens of the world and, thus, have the right to be welcomed by other countries when in need. Throughout history, several social scientists, philosophers of education, and educators (e.g., Banks, 2008; Beck 2000; Dewey, 2004/1916; Habermas, 1996; Held, 1995; Hutchings \& Dannruether, 1999; Kaldor, 2003; Osler \& Starkey, 2003, 2005; Osler \& Vincent, 2002) have identified with the cosmopolitan citizenship approach to education. Osler and Starkey (2005), for example, argue that cosmopolitan citizenship is a status, a feeling, and a practice at all levels, from the local to the global. They explain that "students are holders of inalienable human rights, rather than their presumed status as citizens" (Osler \& Starkey, 2011, p. 2). Freedom and equity are not rights bestowed by certain countries, but are rights that should be respected and fought for by the entire global community.

Appadurai (1996) suggests a citizenship approach that is linked to material problems and suggests that it is time to rethink the nation-state patriotism in order to:

allow the material problems we face - the deficit, the environment, abortion, race, drugs, and jobs - to define those social groups and ideas for which we would be willing to live and die [...] Some of us may still want to live - and die for the United States. But many of these new sovereignties are inherently postnational. (p. 176)

Instead of imposing one type of nationality, state members should be able to choose a cause through which they want to improve life on this planet. Nussbaum (1994) argues that cosmopolitan citizenship should be the central focus of education because it gives individuals the opportunity to learn more about themselves, develop empathy, and work together to solve problems that affect humanity and the environment and that require local, national and international cooperation.

Nevertheless, opposition to the ideal of cosmopolitanism abounds. Pheng Cheah (1998) explains that Marx saw cosmopolitanism as a way of exploiting the world through a 


\section{ACTES DU SJPD-JPDS PROCEEDINGS, 2018, VOL. 2}

global mode of production and the establishment of international commerce. According to Marx (1848/1973), "the bourgeoisie has through its exploitation of the world market given a cosmopolitan character to production and consumption in every country [... as well as] the intellectual creations of individual nations" (p. 71). The father of modern China, Sun Yat-sen (1927) also stood opposed to an independent cosmopolitanism. He insisted that a nation needs to establish a strong nationalism and that "we must understand that cosmopolitanism grows out of nationalism. If nationalism cannot become strong, cosmopolitanism certainly cannot prosper" (p. 89). Taylor (2012) agrees with Sun Yat-sen; he argues that without nationalism humans would not be able to contribute towards a common wellbeing because they would be more focused on their own individual welfare. Taylor explains that two facts influence nationalism. One is identity, which refers to how individuals see themselves in relation to the group; the other is the members' belief that their participation in society is important. Without identity and belief there would not be group cohesion and individuals would become more focused on securing their own individual rights. Consequently, for cosmopolitanism to exist, societies should also be nationalistic to some extent.

In 1994, Richard Rorty wrote "The Unpatriotic Academy", which inspired Nussbaum and other academics to publish the book For the Love of Country: Debating the Limits of Patriotism (1996). Rorty (1994) discusses the need for a national identity and a national pride instead of a "politics of difference" (para. 10), which he deems unpatriotic and ineffective. He explains that loyalty to a small group has the potential to motivate individuals to cooperate with the larger group, and further, that it is actually unjust for someone to try to solve universal conflicts while ignoring local ones.

Cheah (1998) depicts Benedict Anderson as the most popular defender of nationalism who believes that it is universalistic, unlike the migrants who keep their bounded political identities. In fact, Anderson (1991) and Tönnies (1957/1887) argue that the principle of nationality is influenced by technology, which under the influence of globalization, has acquired a transnational perspective.

Robbins (1998) believes that nationalism and cosmopolitanism can share a path, because commitment to people's wellbeing is linked to history and sentiments (e.g., religion, friendship, commercial interests, recognition of unfairness, such as child labor and hunger), not to the abstraction of humanity. However, the reason he opposes cosmopolitanism is because he sees it as an "outgrowth of ideological reflection of global capitalism" (p. 7) that aims to impose a philosophy of western universalism while ignoring individual and group identities. 


\section{ACTES DU SJPD-JPDS PROCEEDINGS, 2018, VOL. 2}

Cosmopolitan citizenship values and promotes individual, national and global identities and gives citizens the freedom to be involved in citizenship at all levels. Through CCE, students learn to see humanity through the lenses of equity, and respect and protect the environment as everyone's home. Their learning may lead them to want to advocate for peace, human rights and sustainability and CCE will assist them in their journey.

\section{Theoretical Framework}

The objective of this study was to conduct a critical discourse analysis of two Ontario curriculum documents: (1) The Grades 9 and 10: Canadian and World Studies (OME, 2018), which addresses civic education, and (2) the Grades 9 to 12: English as a Second Language (ESL) and English Literacy Development (ELD) (OME, 2007), which prepares newcomers to improve their English proficiency. These two documents were chosen because they affect the learning of every secondary student in Ontario, whether born in Canada or abroad. The Canadian and World Studies course is mandatory for all students, while the ESL - EDL courses are mandatory for students whose mother tongues are other than English and for "students who speak a variety of English such as those spoken in parts of the Caribbean and Africa" (OME, 2007, p. 21). Although these are not explicitly considered citizenship courses, they constitute newcomer secondary students' first experience with the Canadian educational system.

The theoretical framework used in the study includes CP and CCE, because they embrace principles that can be shared in the classroom to promote critical cosmopolitan citizens who care about humanity and the environment. While analyzing the curriculum documents, I investigate whether the document states expectations instead of suggestions that would give both teacher and student any opportunity to inquire about subjects of their own interest. CP argues that students and teachers need to have the right to choose what to learn for learning to be empowering. In addition, I seek evidence of demonstration of global interdependence instead of only theoretical knowledge that depicts the other as far away and not belonging to the local reality. Cosmopolitan citizenship is inclusive of all levels of citizenship. 


\section{ACTES DU SJPD-JPDS PROCEEDINGS, 2018, VOL. 2}

\section{Methods}

\section{Critical Discourse Analysis}

Discourse analyses are part of a critical social analysis approach that views language as an expression of social relations connected to historical contexts, which can be accepted or challenged according to existing social values (Fairclough, 2012). Critical discourse analysis focuses on the correlation between discourse and social elements, such as relations of power (Janks, 1997).

The technical procedure used in this study is based on Chouliaraki and Fairclough's (1999) four stages of discourse analysis, which, according to Fairclough (2012), is a variant of Bashar's explanatory critique. These stages include: "Stage 1: Focus upon a social wrong, in its semiotic aspects. Stage 2: Identify obstacles to addressing the social wrong. Stage 3: Consider whether the social order 'needs' the social wrong. Stage 4: Identify possible ways past the obstacles" (Fairclough, 2012, p. 12).

Stage 1: Focus upon a social wrong, in its semiotic aspects. The present study analyzed two Ontario curriculum documents to identify indications of harmful power dynamics that may contribute to injustice towards racialized newcomers. Fairclough (2012) emphasizes that the researcher must select a topic related to a social wrong "which can productively be approached in a trans-disciplinary way with a particular focus on dialectical relations between semiotic and other 'moments'” (p. 6). Cui (2015), Hall (1992) and Hage's (2000) studies show a concern about the dichotomy of the Canadian educational system that favours white, Canadian born students and hinders newcomers and non-white groups, which are described as social wrongs. In Ontario, curriculum documents are funded and written by the provincial ministry of education. According to Luke (1995), when the government decides what, how and why teachers will educate the students, they retain great power over the educational system. In addition, Apple (1985) asserts that it is necessary to analyze the work of education through a social lens to understand how particular perspectives, methods and "truths" are made available.

Stage 2: Identify obstacles to addressing the social wrong. Once the obstacles were identified, it was necessary to disclose them. Fairclough (2012) explains that the social wrong addresses the ways in which "social life is structured and organized that prevents it from being addressed" (p. 7). Since the Ontario curriculum is written and imposed by the 


\section{ACTES DU SJPD-JPDS PROCEEDINGS, 2018, VOL. 2}

government that also funds education in the province, they stand very powerful before educators and learners inhibiting any opposing standpoint.

The obstacles to address the social wrong revolve around the powerful political discourse that dominates education and the influence of neoliberalism that sabotages public values and sees education as a way of training students (Giroux, 2014). Like a rhizome that is invasive and difficult to destroy, neoliberalism develops mostly underground, influencing people's social, cultural and professional lives, seeking ultimately to destroy group identity and promote a society that is individualistic, consumerist and competitive (Jones, 2011). This type of society will only promote inequality and conflict, which opposes the fundamental principles of cosmopolitan citizenship.

It is the goal of every government in more developed countries for youth to finish high school and move on to post-secondary education or into the workforce. Students learn from a very young age that without school, there is no future (Ball, Maguire, \& Macrae, 2000), so it is difficult to confront a system that exists, in part, to structure each person's life. Many times, the problem begins in elementary school, when students who show poor academic skills begin to feel that they do not belong in that system. When learners do not fit into the educational social order and drop out, society holds them responsible for their choices instead of questioning the structural and institutional constraints facing them (Bourdieu et al., 1999). In addition, they tend to be ostracized by society because they will need assistance to survive, instead of becoming powerful consumers.

Stage 3: Consider whether the social order 'needs' the social wrong. In a globalized economy and society, it would be ideal for members of all races, ethnicities, classes and genders to be treated equally. Indeed, Fairclough (2012) posits that "discourse is ideological in so far as it contributes to sustaining relations of power and domination" (p. 8). When power is used to exert imbalance between the citizens of a country, it promotes social wrongs that damage the social order and need to be addressed and changed. The Ontario educational system has structured education as preparation for the test, which is "instrumental and reductionist" (Giroux, 2014, p. 491) and serves to disempower students and reduce teachers' capabilities to a simple-minded role. This is not an inclusive system because it is developed for the hegemonic group that monopolizes the economy, curbing the possibilities of minority groups to succeed in society. In fact, Ontario schools have seen an increase in violence and reduction of funding to support those who need extra care (Hammond, 2018). 


\section{ACTES DU SJPD-JPDS PROCEEDINGS, 2018, VOL. 2}

Stage 4: Identify possible ways past the obstacles. According to Fairclough (2012), stage four "moves the analysis from negative to positive critique: identifying, with a focus on dialectical relations between semiosis and other elements, possibilities within the existing social process for overcoming obstacles to addressing the social wrong in question" (p. 8). CP and CCE offer a positive change to education and to citizenship. Through this approach students and teacher are able to nourish critical thinking, inquire, ask questions and become agents of change; education becomes the berceau (haven) of "social movements capable of struggling against anti-democratic force" (Giroux, 2014, p. 497) that ignore human rights, peace and environment consciousness.

\section{Document Analysis}

This section will present the critical analysis of The Ontario Curriculum Grades 9 and 10: Canadian and World Studies (OME, 2018) and The Ontario Curriculum Grades 9 to 12: English as a Second Language and English Literacy Development (OME, 2007). I explain the visions of the two documents and how they depict their expectations. I also try to find an indication of strands of CCCE in both documents.

\section{Ontario's Canadian and World Studies Curriculum}

The Ontario curriculum grades 9 and 10: Canadian and World Studies (OME, 2018) suggests that the curriculum "provides opportunities for teachers and students to select, within the broad parameters of the expectations, topics for investigation" (p. 40); however, in the same paragraph, it states that the teacher should plan the learning unit with the "end in mind" and select the "appropriate content, including issues and examples, and ensuring that students develop the knowledge, understanding, and skills to support this end [the planned unit]" (p. 40). At times, it seems the document is giving teachers and students a certain freedom to direct the learning in the classroom; however, upon deeper examination, it is in fact controlling what should happen in the classroom, imposing its goals on youth provincewide who have different worldviews and needs, and forcing students to be mere passive containers of unfamiliar knowledge.

Ontario's Canadian and World Studies Curriculum for grades 9 and 10 (OME, 2018) incorporates a previous environmental policy entitled: Acting Today, Shaping Tomorrow: A Policy Framework for Environmental Education in Ontario Schools. This policy acknowledges the need for all Ontario students to become environmentally responsible and outlines three goals: promoting environmental learning, engaging students to advocate for the 


\section{ACTES DU SJPD-JPDS PROCEEDINGS, 2018, VOL. 2}

environment, and designating individuals and organizations within the education system to encourage teachers and students to continue their journeys as environmental supporters. The curriculum document does not mention that students need to be involved in activities that promote sustainability in a global scope, but rather, suggests that students are encouraged to "explore a range of environmental issues [related to] Canadian resource management, population growth and urban sprawl, and the impact of human activity on the natural environment" (p. 46). This discourse indicates that students should learn about how global issues affect Canada, but not how Canada affects the world. It does not position Canada as a member of the global community with responsibilities to improve life on Earth (in addition to life in Canada) and help other countries focus on the global wellbeing.

Through a CCCE approach, students and teachers would become aware of a problem (e.g., the global water crisis), and explore aspects such as scarcity and pollution within the local, national and global contexts. Beyond awareness, CCCE would motivate students to extend their investigation to seek understanding of those problems and would encourage them to identify realistic ways of helping improve the situation and prompt them to act.

The stated objective of the Ontario Canadian and World Studies Curriculum as a policy document, which is used to guide to Geography, History and Civics (politics) education, is to "enable students to become responsible, active citizens within the diverse communities to which they belong, as well as becoming critically thoughtful and informed citizens who value an inclusive society" (p. 6). This vision for the three courses contained in the document relies on an understanding of complex terms, including: active citizenship, diversity in communities, critical thought, and inclusive societies (concepts which can be interpreted in different ways). The curriculum defines civics education, for example, as "a branch of politics that explores the rights and responsibilities of citizens, the processes of public decision making, and ways in which citizens can act for the common good within communities at the local, national, and/or global level" (p. 12). While Ontario teaches civics education, Starkey (2012) explains that there is a difference between civics and citizenship education. Civics education was introduced in the 19th century with the implementation of an educational focus on the national state, dissociating from values such as humanity and cosmopolitanism that had been defended earlier (e.g., by Kant in 1903), and instead promoting nationalism (Dewey, 2004/1916). Starkey (2012) clarifies that citizenship education differs from civics education because it welcomes dialogue and visualizes change occurring through a democratic approach. The OME's choice of adopting a civics approach to education demonstrates a governmental preference that endorses a nationalist quizas (perhaps) patriotic country instead of a more democratic and inclusive one. 


\section{ACTES DU SJPD-JPDS PROCEEDINGS, 2018, VOL. 2}

The analysis of the first Ontario curriculum document led me to conclude that the curriculum aims to prepare students to become promoters of a common good and to act in the name of others as knowledgeable outsiders. That is, it seems to encourage individuals who theoretically understand someone else's problems to act, instead of bringing the insiders (i.e., those who experience the problem) into the action. This can be problematic because the ideology that drives the out-group's promotion of the common good may not match the in-group's ideology. If the supposedly knowledgeable out-group members do not work with the in-group to find a solution (even if well-intentioned), their decision for the common good could be considered oppressive. Indeed, according to Freire (1972), decisions made by an out-group in a paternalistic manner to help the oppressed without giving them the freedom to decide for themselves does constitute oppressive action. Consequently, learning through The Ontario Curriculum Grades 9 and 10: Canadian and World Studies (OME, 2018) may not prepare students to understand and accept otherness, but may instead contribute to maintenance of an oppressed-oppressor dynamic within society.

\section{Ontario's ESL - ELD Curriculum}

The vision of The Ontario Curriculum Grades 9 to 12: English as a Second Language and English Literacy Development (OME, 2007) is that the English language learner acquires the necessary language skills to become a full participant in Canadian society. Although it acknowledges that over 100 different languages are spoken in Ontario's secondary schools, there is no attempt to include this diversity in the teaching and learning process; rather, the emphasis of the courses is on preparing newcomers to participate effectively in the job market. In order to curtail any attempt to deviate from the curricular expectations, and potentially also to demonstrate power over teachers and learners, the document frequently uses words and phrases such as "expected", "essential", "required" and "students will...". For example, "knowledge and skills that students are expected to develop and demonstrate in their class work" (p. 15); "structures students are expected to learn through work done" (p. 172); "essential classroom and school routines and behaviour" (p.126); "skills and work habits required for success in the workplace" (p.181); "students will be expected to use [...] sources with increasing sophistication" (p. 52) (OME, 2007). The justifications for the goals of the ESL and ELD curriculum (OME, 2007) are:

the belief that broad proficiency in English is essential to students' success in both their social and academic lives and to their ability to take their place in society as responsible and productive citizens. The curriculum is designed to provide English 


\section{ACTES DU SJPD-JPDS PROCEEDINGS, 2018, VOL. 2}

language learners with the knowledge and skills they need to achieve these goals. (p. 3).

While this statement may be true, the document's almost exclusive focus on this aim overlooks other important topics such as citizenship, cultural and social diversity, and equity of all citizens, producing a hegemonic discourse that indirectly encourages newcomers to master the English language simply in order to acculturate and contribute financially to society.

According to Dewey (2004/1916), a democratic society is formed by continuous interactions of social groups to break down barriers of "class, race, and national territory which [has] kept men form perceiving the full import of their activity" (p. 91). Dewey explains that only education can revoke undemocratic principles and support a democratic society through inclusion and equity. The primary goal of Ontario's ESL - ELD curriculum document (OME, 2007) appears to be to prepare newcomers to participate in the job market, disregarding their right to experience full Canadian citizenship, which allows full participation in social and political domains.

\section{Discussion}

The initial review of the two Ontario curriculum documents displayed a lack of education for activism and empowerment to build a better world. New Canadian citizens are not blank slates; they are individuals with their own cultural and social backgrounds who need to adjust to a new culture and society, but who also have a lot to contribute to the betterment of their new home. Cui (2015) explains that if newcomers are not given the opportunity to share their beliefs with the new society, they may never develop a feeling of belonging. If newcomers do not embrace a Canadian identity, they probably won't feel responsible for the country or the people who live here, which could create conflicts with native-born citizens. However, through the CCCE approach, learners can be encouraged to develop thoughtful and positive relationships with their local groups, nation-states, and the global community. In addition, through critical consciousness (Freire, 1972) they will feel empowered to join with other groups to intervene in the world and transform it for the better. I believe this approach would help to counteract the feeling of not belonging to the Canadian society because individuals are treated as members of humanity as a whole and as citizens of the Earth. 


\section{ACTES DU SJPD-JPDS PROCEEDINGS, 2018, VOL. 2}

The United Nations Declaration on Human Rights Education and Training (2011) defines activism as a movement for change that begins with self and includes various levels of human interactions. It distinguishes between education about rights (i.e., awareness of the principles of human rights), education through rights (i.e., student understanding of their own rights), and education for rights (i.e., learner empowerment to use their rights to help others). All forms of education are valid and important; however, education for rights has the capacity to motivate students to try to affect positive change in the world. Ultimately, the Ontario curriculum documents analyzed in this paper focus on education about rights and through rights, but they fail to empower the students to learn for the rights of others.

\section{Conclusion}

The internet, scientists, educators and many UN and NGO agencies have revealed the global imbalance of income distribution and nature depredation. While many humans struggle to survive, a minority of wealthy people live a life of luxury and waste. In the name of capitalism, forests are being destroyed, pollution is increasing, and consumption by the rich is being encouraged. This discrepancy needs to end, however, simple awareness of this global and local unfairness will not change reality. Education has a very important role to play in transforming the world into a better place to live. Implementing an educational approach that combines critical pedagogy and cosmopolitan citizenship education will prepare learners to be critical of the status quo while learning to advocate for human rights, peace and sustainability. Given these benefits, it is reasonable to assert that the critical cosmopolitan citizenship education approach is the ideal way to overcome global inequities within the ambits of human-human and human-nature relations. It promotes action for the betterment of the world, because knowledge without action does not promote change.

The critical part of the CCCE approach empowers students to develop thoughtful and positive relationships with their local communities, nation-states, and the global society to make real change (Freire, 1972). It refutes the idea that individuals should define themselves "within an atomized framework, in which competitiveness is the ever present and overriding goal of all activity" (Copley, 2018, p. 45). As such, CCCE counteracts racism and the feeling of not belonging to the Canadian society, because it promotes a view of all humans as valuable citizens of the world. Although this approach to citizenship may sound utopic, cosmopolitanism has already been adopted by the global society. Examples of cosmopolitanism's reach include the United Nations, the International Court of Justice, international non-governmental organizations, such as the World Health Organization, and many other transnational organizations. The idea of a cosmopolitan world may not attract 


\section{ACTES DU SJPD-JPDS PROCEEDINGS, 2018, VOL. 2}

everyone, especially those who believe in a strong and independent nation-state, but I believe adopting a CCCE approach would empower students to target injustices in the local, national and global sphere, and will contribute to a better life on this planet.

This paper's critical discourse analysis of the two Ontario curriculum documents on Canadian and World Studies and ESL - ELD demonstrates a need for the Ontario government to make changes to their approach to citizenship and newcomer language education in order to nurture a peaceful and participatory society. The study further reveals that instead of civics education that is normative and limiting, a critical cosmopolitan citizenship approach is ideal because it empowers and motivates learners to become active citizens in society. Specifically, the CCCE approach encourages awareness of inequities and active involvement in movements of change, as opposed to remaining apathic to injustice and contributing (even if indirectly) to a world of inequities and war. Indeed, CCCE is a transdisciplinary approach because injustices can be addressed through any subject matter, but especially language. When learning through this approach, newcomers would have the opportunity to share their beliefs, learn from others and become full citizens of Canada and the world, instead of focusing solely on financial success, which could result in selfish, apathetic individuals with no sense of belonging or interest in building a better country or world.

Finally, as this is a theoretical study, the absence of teacher perspectives is a limitation because their understanding of the curriculum has the potential to bring more insight to this inquiry. Although teachers' actions are also controlled by curriculum documents, many are driven by a passion for justice and still find ways to address social, financial, cultural and environmental struggles in the classroom. Sharing their experiences could inspire other teachers to inspire future learners. After all, teachers are the experts who guide student learning and may influence their journey to become effective citizens in society. In order to build on the present study and bridge the gap between theory and practice, future studies aiming to bring in teachers' perspectives (on these and other relevant curriculum documents) are suggested. 


\section{ACTES DU SJPD-JPDS PROCEEDINGS, 2018, VOL. 2}

\section{References}

Anderson, B. (1991). Imagined communities: Reflections on the origin and spread of nationalism. London, UK: Verso.

Appadurai, A. (1996). Modernity at large: Cultural dimensions of globalization. Minneapolis, MN: University of Minnesota Press.

Appiah, K. A. (2006) Cosmopolitanism: Ethics in a World of Strangers New York, NY: W. W. Norton \& Company.

Apple, M. W. (1985). Teachers and texts. New York, NY: Routledge \& Kegan Paul.

Apple, M. A. \& Beane, J. A. (Eds.) (1995). Democratic schools. Alexandria, VA: ASCD.

Ball, S. J., Maguire, M. \& Macrae, S. (2000). Choice, Pathways and Transitions Post-16: New Youth, New Economies in the Global City. London: RoutledgeFalmer.

Banks, J. A. (2008). Diversity, group identity, and citizenship education in a global age. Educational Researcher, 37(3), 129-139.

Baxter, P., \& Jack, S. (2008). Qualitative case study methodology: Study design and implementation for novice researchers. The Qualitative Report, 13(4), 544-559.

Beck, U. (2000). What is globalization? Cambridge, UK: Polity Press.

Beck, U., \& Sznaider, N. (2006). Unpacking cosmopolitanism for the social sciences: a research agenda. The British Journal of Sociology, 57(1), 1-23.

Bourdieu, P., Accardo, A., Balazs, G., Beaud, S., Bonvin, F., \& Bourdieu, E. (1999). The Weight of the World: Social Suffering in Contemporary Society. Cambridge, UK: Polity Press.

Bootrach, P., Thiengkamol, N., \& Thiengkamol, T. K. (2015). Environmental education strategy. Applied Environmental Education \& Communication, 14(4), 200-212.

Cheah, P. (1998). The Cosmopolitical - Today. In Pheng, C. \& Bruce, R. (Eds.), Cosmopolitics, thinking and feeling beyond the nation. Cultural Politics (pp. 20-44). Minneapolis, MN: University of Minneapolis. 


\section{ACTES DU SJPD-JPDS PROCEEDINGS, 2018, VOL. 2}

Chouliaraki, L., \& Fairclough, N. (1999). Discourse in late modernity. Edinburgh, UK: Edinburgh University Press.

Cui, D. (2015). Capital, distinction, and racialized habitus: Immigrant youth in the educational field. Journal of Youth Studies, 18(9), 1154-1169.

Darder, A, Baltodano, M., \& Torres, A. (2003). The Critical pedagogy reader. New York, NY: Routledge Falmer.

Dewey, J. (2004). Democracy and education. Mineola, NY: Dover Publications Inc. (Original work published 1916).

Hammond, S. (2018, January 23). 70\% of Ontario elementary teachers personally faced violence in the classroom: Union, Global News. Retrieved from https://globalnews.ca/video/rd/1144020035522/?jwsource=cl

Fairclough, N. (2012). Critical discourse analysis. In J. P. Gee \& M. Handford (Eds.) The Routledge handbook of discourse analysis (pp. 9 - 20). New York, NY: Routledge.

Foucault, M., \& Gordon, C. (1980). Power/knowledge: Selected interviews and other writings, 1972-1977 (1 $1^{\text {st }}$ American edition). New York, NY: Pantheon Books.

Freire, P. (1972). The pedagogy of the oppressed. New York, NY: The Seabury Press.

Gray, J. \& Zilio, M. (2018, July 5). Ontario, federal government battle over resettling migrants. The Globe and Mail. Retrieved from https://www.theglobeandmail.com/canada/article-ontario-withdraws-support-forresettlement-of-asylum-seekers-who/

Giroux, H. (1983). Theory \& resistance in education: A pedagogy for the opposition. London, UK: Heinemann.

Giroux, H. (2014). When Schools Become Dead Zones of the Imagination: a critical pedagogy Manifesto. Policy futures in education, 12(4), 491-499.

Habermas, J. (1996). Between facts and norms: Contributions to a discourse theory of law and democracy. Cambridge, UK: Polity Press. 


\section{ACTES DU SJPD-JPDS PROCEEDINGS, 2018, VOL. 2}

Hage, G. (2000). White nation: Fantasies of white supremacy in a multicultural society. New York, NY: Routledge.

Hall, S. (1992). The Future of Identity. In T. McGrew \& S. Hall (Eds.) Modernity and Its Futures (pp. 274-316). Cambridge, UK: Polity Press.

Held, D. (1995). Democracy and the new international order. In D. Archibugi \& D. Held (Eds.) Cosmopolitan democracy: An agenda for a new world order (pp. 96-120). Cambridge, UK: Polity Press.

Hutchings, K. \& Dannruether, R. (Eds.) (1999). Cosmopolitan citizenship. Basingstoke, UK: Macmillan.

Janks, H. (1997). Critical discourse analysis as a research tool. Discourse: Studies in the Cultural Politics of Education, 18(3), 329-342.

Jones, O. (2011). Chavs: The demonization of the working class. London, UK: Verso.

Kaldor, M. (2003). American power: From 'compellance' to cosmopolitanism? International Affairs, 79(1), 1-22.

Kant, I. (1903). Perpetual peace: A philosophical essay,1795. London: S. Sonnenschein. (Original work published 1795).

Kincheloe, J. (2007). Critical pedagogy in the 21 st century: Evolution for survival. In P. McLaren \& J. Kincheloe (Eds.). Critical pedagogy: Where are we now? (pp. 147-183), New York, NY: Peter Lang.

Marx, K. (1973). Manifesto of the Communist Party, The Revolutions of 1848: Political writings,1. Harmondsworth: Penguin (Original work published in 1848).

McLaren, P. (1994). Life in schools: An introduction to critical pedagogy in the foundations of education. New York, NY: Longman.

Leblanc, Raymond (2018). La qualité de vie pour tous. Unpublished manuscript, Department of Education, University of Ottawa, Ottawa, Canada.

Luke, A. (1995). Text and discourse in education: An introduction to critical discourse analysis. Review of Research in Education, 21(1), 3-48. 


\section{ACTES DU SJPD-JPDS PROCEEDINGS, 2018, VOL. 2}

Ontario Ministry of Education. (2007). The Ontario curriculum grades 9 to 12: English as a second language and English literacy development, Retrieved from http://www.edu.gov.on.ca/eng/curriculum/secondary/es1912currb.pdf

Nussbaum, M. (1994, October 1). Patriotism and cosmopolitanism. Boston Review: A Political and Literary Forum. Retrieved from http://bostonreview.net/martha-nussbaumpatriotism-and-cosmopolitanism

Nussbaum, M. (1996). For love of country: Debating the limits of patriotism. Boston, MA: Beacon Press.

Nussbaum, M. (2003). Capabilities as fundamental entitlements: Sen and social justice. Feminist Economics, 9(2-3), 33-59.

Ontario Ministry of Education. (2018). The Ontario curriculum grades 9 and 10: Canadian and World Studies.

Osler, A. (2011). Teacher interpretations of citizenship education: National identity, cosmopolitan ideals, and political realities. Journal of Curriculum Studies, 43(1), 1-24.

Osler, A., \& Starkey, H. (2005). Changing citizenship: Democracy and inclusion in education. Maidenhead, UK: Open University Press.

Osler, A., \& Starkey, H. (2003). Learning for cosmopolitan citizenship: Theoretical debates and young people's experiences. Educational Review, 55(3), 243-254.

Osler, A., \& Vincent, K. (2002). Citizenship and the challenge of global education. StokeonTrent, UK: Trentham.

Robbins, B. (1998). Actually existing cosmopolitanism. In P. Cheah \& B. Robbins (Eds.), Cosmopolitics: Thinking and feeling beyond the nation: Vol. 14 Cultural politics (pp. 119). Minneapolis, MN: University of Minnesota Press.

Rorty, R. (1994, February 13). The unpatriotic academy. New York Times. Retrieved from: https://www.nytimes.com/1994/02/13/opinion/the-unpatriotic-academy.html

Starkey, H. (2012). Human rights, cosmopolitanism and utopias: Implications for citizenship education. Cambridge Journal of Education, 42(1), 21-35. 


\section{ACTES DU SJPD-JPDS PROCEEDINGS, 2018, VOL. 2}

Sun, Yat-sen. (1927). San Min Chu I [The three principles of the people]. Shanghai, China: Committee Institute of Pacific Relations.

Taylor, C. (2012). Why democracy needs patriotism. In M. Nussbaum \& J. Cohen (Eds.), For the love of Country (pp. 119-121). Boston, MS: Beacon Press.

Tönnies, F. (1957). Community and society. East Lansing, MI: Michigan State University Press (Original work published in 1887).

Angus Reid Institute. (2018, August 3). Two-thirds call irregular border crossings a 'crisis,' more trust Scheer to handle issue than Trudeau. Retrieved from http://angusreid.org/safe-third-country-asylum-seekers/

United Nations, General Assembly. (2011). United Nations declaration on human rights education and training. Retrieved from https://www.ohchr.org/en/issues/educatio n/training/pages/undhreducationtraining.aspx 